\title{
Journal of Plant Research chosen as one of the top 100 journals in biology and medicine over the last 100 years
}

\author{
Hirokazu Tsukaya
}

Published online: 3 June 2009

(C) The Botanical Society of Japan and Springer 2009

It is my great pleasure to announce that our journal, the Journal of Plant Research (JPR), has been chosen by the Biomedical and Life Science Division of the Special Libraries Association (SLA) as one of the 100 most influential journals in biology and medicine over the last 100 years. The JPR is the sole journal nominated from Japan. I wish to thank to everyone who helped JPR to receive this honor: all authors, all reviewers, all editors, all publishing staff members, et al. Details of this nomination can be read on the following Website (SLA Biomedical \& Life Sciences Division 2009: http://units.sla.org/division/ dbio/publications/resources/dbio100.html, and here I will report briefly on this wonderful news, with a few comments on the meaning of this nomination.

First, I'd like to explain what SLA is and why SLA chose the 100 most influential journals over the last 100 years. According to the information on the above-mentioned Website, SLA was founded 100 years ago (in 1909) in the United States, by a group of librarians of specialist fields, namely, librarians serving business, government, social agencies, and academic communities. The "Special Libraries" part of the SLA came from these specialist librarians. On the Website (SLA 2009: http://www.sla.org/ content/Events/centennial/centennialmessage.cfm, there is the statement that "SLA is the principal association for

\section{H. Tsukaya ( $\square)$}

Graduate School of Science, The University of Tokyo,

Science Building \#2, 7-3-1 Hongo, Bunkyo-ku,

Tokyo 113-0033, Japan

e-mail: jpreic@biol.s.u-tokyo.ac.jp

\section{H. Tsukaya}

National Institute for Basic Biology,

National Institutes of Natural Sciences,

Okazaki, Japan information professionals and their strategic partners throughout the world. Its 11,000 members come from 75 nations". This nomination is one of the commemorative events celebrating the centennial of SLA.

Next, let us see what journals have been chosen as the 100 most influential in biology and medicine. Of course, the top journals, Nature (from 1869) and Science (1880), are nominated. In the field of plant science-our field-we find the American Journal of Botany (1914), Botanical Journal of the Linnean Society (1855), Botany (1929), International Journal of Plant Sciences (1875), Journal of Experimental Botany (1950), Plant Ecology (1949), Plant Physiology (1926), and Systematic Botany (1976) along with our name. Among them, the American Journal of Botany (AJB) and Botany (formerly the Canadian Journal of Botany) are the journals most similar to JPR in covering a wide range of plant sciences from taxonomy, anatomy, physiology, and ecology to molecular genetics; and there is also a similarity in their being issued by an academic society (AJB by the Botanical Society of America, Botany by the National Research Council Canada, and JPR, as you know, by the Botanical Society of Japan). The nomination of JPR, Botany, and AJB appear to show that this type of general journal for plant science has its own value as a genre.

As seen in all cultural activities in the world, differentiation of activity into many small fields is more and more evident now. Following this trend, not a small number of academic journals have changed their field of coverage from a wider to a narrower one: from being a general journal to one focusing on a particular research field. This type of change of field is expected to increase the Impact Factor (IF) value if the journal shifts its focus to a more popular field than before and also is intended to help to facilitate editorial work. Thus, many commercial journals 
tend to focus on a particular research field. In recent years, editorial members of JPR also have discussed the possibility of making this kind of change with JPR. However, at least at present, we believe we should not adopt such a change for JPR, keeping it a journal that covers a wide range of plant sciences from taxonomy, anatomy, physiology, and ecology, to molecular genetics. In these past few years, we have made an effort to publish papers on systems biology, theoretical biology, and other new areas of study, too. Moreover, the number of editors of JPR has been increased to nine in order to cover the wide range of studies submitted to JPR. This insistence on generality is for two main reasons: (1) The origin of JPR was Shokubutsugaku-Zasshi (Botanical Journal) established in 1887 , as briefly summarized in the editorial of the first issue of this year's JPR (Tsukaya 2009); and (2) JPR is issued by the Botanical Society of Japan, the oldest academic society for plant science in Japan, promoting research activities in all the basic plant sciences. This historical continuity of the journal's style for more than 120 years was, I believe, a consideration for this nomination and is an encouragement from SLA to continue the journal style embodied in JPR.

Encouragement is also to be found in looking at the Impact Factors of the nominated journals. Of course, firstclass journals such as Nature and Science are on the list, but not all the listed journals have high IF values. For example, on the list of the 100 most influential journals, we find that Plant and Cell Physiology (PCP), which is also issued by an academic society in Japan, is not included. On the basis of a simple comparison of the IF value, PCP is better than JPR. This difference is due, at least in part, to better circulation, many readers, and frequent citation in the plant physiology field, on which PCP focuses rather than on other research fields such as plant taxonomy and plant anatomy, which JPR covers. The difficulty of evaluation of the IF among different research fields has long been discussed, and SLA may consider many other factors than the IF in making its selection, thus assigning high value to journal quality.

Of course, the mere length of the journal's history does not qualify it for this kind of honor: "one of the 100 most influential journals in biology and medicine over the last 100 years". The quality of papers published in the journal is the most important point. In this respect, we point with pride to papers on findings of sperm from seed plants that were published in Shokubutsugaku-Zasshi during the first period of our history (Hirase 1896; Ikeno 1896). We believe that not only these early contributions but many other important papers on new findings have been published in JPR. I hope all our readers will continue to contribute to the great history of JPR, by submitting important research findings to our journal.

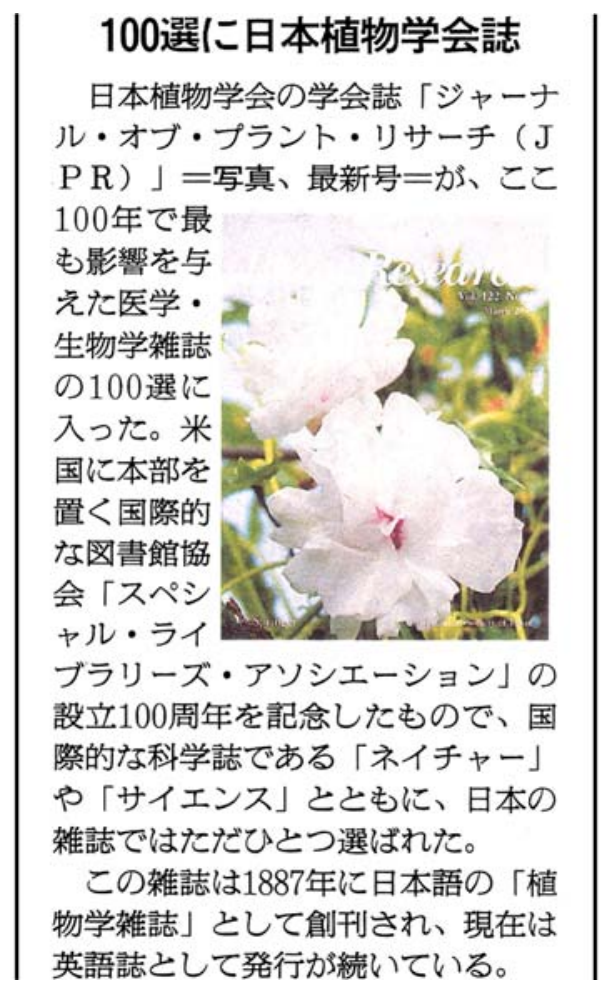

Fig. 1 A report in the Asahi Shimbun (17 April 2009) on the nomination of the Journal of Plant Research as one of top 100 journals in biology and medicine over the last 100 years. Reproduced with permission

In closing, I am happy to report that this nomination was made known to a wide audience among the Japanese population by a report in the Japanese newspaper Asahi Shimbun on 17 April 2009 (Fig. 1) and so on. It is a great honor that JPR can contribute to the promotion of plant science in Japan with this good news. Once again, we thank all who have contributed to the success and recognition of JPR.

Acknowledgments The author thanks the publisher of the Asahi Shimbun for permission to reproduce the newspaper article in Fig. 1.

\section{References}

Hirase S (1896) Ichou-no-seishi-ni-tsuite (On the spermatozoid of Ginkgo biloba) (in Japanese). Shokubutsugaku-Zasshi (Botanical Magazine) 10:325-328

Ikeno S (1896) Sotetsu-no-seichu (Spermatozoid of Cycas revoluta) (in Japanese). Shokubutsugaku-Zasshi (Botanical Magazine) 10:367-377

SLA Biomedical \& Life Sciences Division (2009) DBIO: Top 100 Journals in Botany and Medicine. http://units.sla.org/division/ $\mathrm{dbio/publications/resources/dbio100.html}$

Special Libraries Association (2009) About the Centennial-Special Libraries Association. http://www.sla.org/content/Events/ centennial/centennialmessage.cfm

Tsukaya H (2009) Greetings from the new editor-in-chief. J Plant Res 122:1-2 